\title{
The Impact of Financial Crisis on Asymmetric Foreign Exchange Market Intervention in Emerging Asia
}

\author{
Yanzhen Wang ${ }^{1, a}$, Mingming $\mathrm{Liu}^{1}$, Xiumin $\mathrm{Li}^{1}$ \\ ${ }^{1}$ School of Economics, Northeast Normal University, Changchun, Jilin, China \\ asuifeng19890903@126.com
}

\begin{abstract}
Keywords: emerging Asia, asymmetry, foreign exchange market intervention, generalized method of moments

Abstract: Using asymmetric loss function, this paper estimates asymmetric preference of central bank foreign exchange market intervention in seven emerging Asian economies before and after the 1997-1998 Asian financial crisis and 2008 global financial crisis to reveal the impact of financial crisis on asymmetric foreign exchange market intervention in emerging Asian economies. The estimation results indicate that the 1997-1998 Asian financial crisis makes all sample countries conduct significant asymmetric foreign exchange market intervention against domestic currencies depreciation, while the 2008 global financial crisis makes most emerging Asian economies increase the degree of asymmetric foreign exchange market intervention against domestic currencies appreciation. Besides, during crisis period, more emerging Asian economies tend to conduct stronger asymmetric intervention against nominal exchange rate. While, during non-crisis period, most emerging Asian economies tend to conduct stronger asymmetric intervention against nominal effective exchange rate to maintain their export competiveness.
\end{abstract}

\section{Introduction}

In July 1997, the Asian financial crisis broke out and gradually led to currency crisis. These Asian countries conducted kinds of intervention policies to resist domestic currencies depreciation. After the crisis, these countries began to accumulate foreign exchange reserves in order to avoid similar crisis in the future. Gradually, scholars recognize that the amount of foreign exchange reserves held by these economies is far greater than the amount required for the purpose of financial safeguard. Through research, some scholars conclude that huge foreign exchange reserves in these Asian emerging economies derive from asymmetric foreign exchange market intervention to prevent domestic currencies appreciation by purchasing foreign exchange reserves continuously. This exchange rate management policy is known as "fear of appreciation". ${ }^{[1]}$

After the concept of "fear of appreciation" is put forward, many scholars test asymmetric foreign exchange market intervention of some emerging Asian economies. Using dummy variable method, Ramachandran and Srinivasan (2007) find that the Reserve Bank of India conducts stronger foreign exchange market intervention against rupee appreciation than depreciation. ${ }^{[2]}$ After this research, Srinivasan et al. (2009) uses asymmetric loss function to conclude that the Reserve Bank of India responds much more stronger against rupee appreciation than rupee depreciation. ${ }^{[3]}$ Besides, Cavoli et al. (2008), Pontines and Rajan (2011) and Rajan (2011) use the same method to test asymmetric intervention behavior of India, Indonesia, Philippines, South Korea, Singapore, Thailand and Taiwan China. All results show that sample countries (or regions) conduct stronger foreign exchange market intervention against domestic currencies appreciation than depreciation. ${ }^{[4-6]}$

In addition, some scholars employ nonlinear time series analysis techniques to research this issue. Stigler et al. (2009) use momentum threshold autoregressive model (MTAR) to study structural change of exchange rate regime and evolution of asymmetric intervention behavior of central bank foreign exchange market intervention in India. ${ }^{[7]}$ Pontines and Siregar (2012a, 2012b) use two-regime smooth transition auto-regression (STAR) model and Markov-regime switching method to study central bank asymmetric intervention in Indonesia, the Philippines, South Korea and Thailand. ${ }^{[8-9]}$ Although using different methods, these studies also indicate that sample countries conduct asymmetric foreign exchange market intervention in foreign exchange market. 
Some scholars also study China's asymmetric intervention against RMB appreciation. Du et al. (2010) confirm that China's central bank conducted one-direction asymmetric intervention to prevent RMB appreciation using dummy variable method. ${ }^{[10]}$ Adopting exponential linear asymmetric loss function method, Wang and Li (2014) proved that central bank of China conduct muted asymmetric intervention in foreign exchange market against RMB appreciation, which is defined defensive orientation of exchange rate policy. ${ }^{[11]}$

In conclusion, empirical research on asymmetric preference of central bank foreign exchange market intervention starts from the end of Asian financial crisis. Although scholars realize that the phenomenon of hoarding foreign exchange reserves in emerging Asian economies begins in the end of Asian financial crisis and this phenomenon is related to "fear of appreciation" exchange rate management policy, scholars have not yet studied the impact of financial crisis on asymmetric foreign exchange market intervention. In addition, the 2008 global financial crisis provides another natural experiment to study this issue. Therefore, this paper employs asymmetric loss function to test the effect of financial crisis on asymmetric foreign exchange market intervention in emerging Asian economies.

\section{Central bank's foreign exchange market intervention reaction function}

This paper follows Srinivasan et al. (2009) in specifying central bank's foreign exchange market intervention target and asymmetric loss function. The central bank's target to conduct foreign exchange market intervention is to select an appropriate intervention scale to minimize its loss:

$$
\min _{\left(\mathrm{I}_{\mathrm{t}}\right)} \mathrm{E}_{\mathrm{t}-1} \sum_{\tau=0}^{\infty} \delta^{\tau} \mathrm{L}_{\mathrm{t}+\tau}
$$

Where, $\delta$ is discount factor and $\mathrm{L}_{\mathrm{t}}$ is central bank's loss function in period $\mathrm{t}$.

$$
\mathrm{L}_{\mathrm{t}}=\frac{1}{2}\left(\mathrm{I}_{\mathrm{t}}-\mathrm{I}^{*}\right)^{2}+\frac{\lambda}{2}\left\{\left(\widetilde{\mathrm{e}}_{\mathrm{t}}-\widetilde{\mathrm{e}}^{*}\right)^{2}+\frac{\gamma}{3}\left(\widetilde{\mathrm{e}}_{\mathrm{t}}-\widetilde{\mathrm{e}}^{*}\right)^{3}\right\}
$$

Where, $\lambda>0$ is relative weight and $\gamma$ is asymmetric preference parameter. $\tilde{\mathrm{e}}_{\mathrm{t}}$ denotes the percent change in exchange rate $e_{t}$, and $e_{t}$ is domestic currency nominal exchange rate (domestic currency price of one unit of USD) or nominal effective exchange rate. $\widetilde{\mathrm{e}}^{*}$ is central bank's target value of percent change in exchange rate, which is assumed to be $0 . I_{t}$ is the scale of foreign exchange market intervention and $\mathrm{I}^{*}$ is optimal intervention scale, which is assumed to be constant.

If $\gamma=0$, equation (2) collapses to symmetrical loss function, while if $\gamma \neq 0$, deviation of the same size but opposite sign of $\tilde{\mathrm{e}}_{t}$ from $\tilde{\mathrm{e}}^{*}$ will generate different loss. Specifically, if $\gamma>0$, $\tilde{\mathrm{e}}_{t}-$ $\tilde{\mathrm{e}}^{*}>0$ will yield greater losses, if $\gamma<0, \tilde{\mathrm{e}}_{\mathrm{t}}-\tilde{\mathrm{e}}^{*}<0$ will yield greater losses.

It is assumed that foreign exchange market intervention can reduce the percent change in exchange rate:

$$
\tilde{\mathrm{e}}_{\mathrm{t}}-\tilde{\mathrm{e}}^{*}=\mathrm{a}_{0}+\mathrm{a}_{1} \mathrm{I}_{\mathrm{t}}+\varepsilon_{\mathrm{t}}
$$

Where, $\mathrm{a}_{0}$ and $\mathrm{a}_{1}$ are parameters, $\varepsilon_{\mathrm{t}}$ is the error term with zero mean and variance $\sigma_{\varepsilon}^{2}$. Minimizing Equation (1) by choosing $I_{t}$ subject to the constraint (3) leads to the following intervention reaction function:

$$
\mathrm{I}_{\mathrm{t}}=\mathrm{I}^{*}-\lambda \mathrm{a}_{1} \mathrm{E}_{\mathrm{t}-1}\left\{\tilde{\mathrm{e}}_{\mathrm{t}}+\frac{\gamma}{2}\left(\tilde{\mathrm{e}}_{\mathrm{t}}\right)^{2}\right\}
$$

Replacing the expected values with the actual values, the empirical version of the central bank's foreign exchange market intervention reaction function can be simplified as follows:

$$
\mathrm{I}_{\mathrm{t}}=\mathrm{c}+\alpha \tilde{\mathrm{e}}_{\mathrm{t}}+\beta\left(\tilde{\mathrm{e}}_{\mathrm{t}}\right)^{2}+\mathrm{v}_{\mathrm{t}}
$$

Where, $\alpha=-\lambda \mathrm{a}_{1}, \beta=\left(-\lambda \mathrm{a}_{1} \gamma\right) / 2$, and the asymmetric preference parameter is $\gamma=2 \beta / \alpha$. If $\gamma$ is significantly different from 0 , it can be concluded that the central bank has asymmetric intervention preference. Particularly, $\gamma>0$ denotes that the central bank has "fear of depreciation" 
tendency against domestic currencies nominal exchange rate or "fear of appreciation" tendency against domestic currencies nominal effective exchange rate. While, $\gamma<0$ denotes opposite explanation. Apart from that, the larger the absolute value of $\gamma$, the stronger asymmetric preference of central bank's foreign exchange market intervention.

\section{Empirical testing and results analysis}

This paper studies the impact of financial crisis on asymmetric foreign exchange market intervention in seven emerging Asian economies using the monthly data from January 1999 to December 2015. Considering that the Asian financial crisis ended in the end of 1998, China, Indonesia and some other countries conducted exchange rate regime reform in July 2005, the global financial crisis broke out with the symbol of Lehman Brothers bankruptcy in September 2008, this paper divides the entire sample period into four subsample periods: January 1994 to December 1998, January 1999 to June 2005, July 2005 to August 2008 and September 2008 to December 2015.

Because data of foreign exchange market intervention is unavailable in most sample countries. Similar to existing research, this paper uses percent change in foreign exchange reserves as a proxy. Variables in Equation (5) are in the logarithmic differential form. $\mathrm{I}_{\mathrm{t}}=\left(\Delta \log \left(\mathrm{R}_{\mathrm{t}}\right)\right) * 100$ with $\mathrm{R}_{\mathrm{t}}$ denotes foreign exchange reserves. And $\tilde{\mathrm{e}}_{\mathrm{t}}=\left(\Delta \log \left(\mathrm{e}_{\mathrm{t}}\right)\right) * 100$ with $\mathrm{e}_{\mathrm{t}}$ denotes domestic currencies nominal exchange rate NER or nominal effective exchange rate NEER. The data is sourced from the IMF's International Financial Statistics (IFS) except that the NEER is sourced from the Bank for International Settlements (BIS).

Since the error terms has potential heteroscedasticity and serial correlation, similar to existing research, this paper employs Generalized Moment Method (GMM) to estimate foreign exchange market intervention reaction function. This paper follows Hansen (1982) and uses an optimal weighting estimate of the covariance matrix to solve serial correlation and heteroscedasticity in the error terms and report robust standard errors.

Table 1 reports estimation results of asymmetric preference parameters of the central bank foreign exchange market intervention for seven emerging Asian economies in four subsample periods. For each period, every country has two sets of results—using nominal exchange rate and nominal effective exchange rate, respectively. Besides, this paper uses $\mathrm{J}_{\text {-statistics }}{ }^{1}$ to decide whether over-identifying restriction of instrument variables comes to existence, that is, whether instrument variables specified in estimation are valid. The $\mathrm{J}$ test in this paper indicates that the hypothesis of valid over-identifying restrictions is never rejected, which means the instrumental variables specified in this paper are all valid ${ }^{2}$.

As can be seen from Table 1, for the time period of January 1994 to December 1998, asymmetric preference parameters for all the seven countries are positive when nominal exchange rate is used, while the parameters are negative when nominal effective exchange rate is used, and all parameters are significant, which implies that these countries react more fiercely to domestic currencies depreciation than appreciation. This is probably because this time period includes Asian financial crisis, during which, Thai baht, Philippine peso, Indonesian rupiah, Malaysian ringgit, Singapore dollar and Korean won depreciate drastically, thus, these countries have to intervene in foreign exchange market to resist domestic currencies depreciation. Among these countries, the degree of asymmetric foreign exchange market intervention against nominal exchange rate is greater than against nominal effective exchange rate in China, Korea, the Philippines, Singapore and Thailand, while India and Indonesia are just the opposite.

\footnotetext{
1 J-statistics is a Hansen's over identifying restriction, which is distributed as a $\chi^{2}(L-K)$ under the null hypothesis of valid over-identifying restrictions, in which $L$ and $K$ are the number of instrumental variables and parameters to be estimated, respectively.

$2 \mathrm{~J}$ statistics and $\mathrm{P}$ values are not reported in paper, but the authors are glad to offer them after requesting. 
Table 1 Estimation results of asymmetric preference parameters

\begin{tabular}{llcccc}
\hline \multirow{2}{*}{ Country } & $\begin{array}{c}\text { Exchange } \\
\text { rate }\end{array}$ & $1994.1-1998.12$ & $1999.1-2005.6$ & $2005.7-2008.8$ & $2008.9-2015.12$ \\
\hline \multirow{2}{*}{ China } & NER & $1.475^{* * *}$ & $-1103.336^{* * *}$ & -0.464 & -0.309 \\
& NEER & $-1.080^{* *}$ & $0.655^{* * *}$ & $0.461^{*}$ & $0.328^{* *}$ \\
India & NER & $0.364^{*}$ & $-0.236^{* *}$ & $-0.196^{* * *}$ & $-0.119^{* *}$ \\
& NEER & $-0.445^{* * *}$ & $1.643^{* *}$ & $1.120^{* * *}$ & $0.294^{* * *}$ \\
Indonesia & NER & $0.228^{*}$ & $-0.098^{* *}$ & $-0.294^{* *}$ & $-0.333^{* * *}$ \\
& NEER & $-0.368^{*}$ & $0.152^{* *}$ & $0.727^{*}$ & $0.816^{* * *}$ \\
Korea & NER & $0.208^{*}$ & $-0.468^{* * *}$ & $-0.299^{* * *}$ & $-0.336^{* * *}$ \\
& NEER & $-0.161^{*}$ & $0.341^{* * *}$ & $0.289^{* * *}$ & 0.324 \\
Philippines & NER & $0.500^{* *}$ & $0.363^{* * *}$ & $-0.595^{* *}$ & $-0.650^{* * *}$ \\
& NEER & $-0.397^{* * *}$ & $-0.261^{* * *}$ & $0.281^{* * *}$ & $0.300^{* *}$ \\
Singapore & NER & $0.160^{* * *}$ & $-0.479^{* * *}$ & $-0.314^{* * *}$ & $-0.349^{*}$ \\
& NEER & $-0.152^{* *}$ & $0.519^{* *}$ & $0.455^{* * *}$ & 0.395 \\
Thailand & NER & $0.513^{*}$ & $-0.440^{* * *}$ & $-0.286^{* * *}$ & $-0.349^{* * *}$ \\
\hline
\end{tabular}

Notes: (1) Newey-West method is adopted to estimate the covariance matrix, so as to control heteroscedasticity and serial correlation in error terms. (2) The standard deviation of parameter $\gamma$ is calculated using the Delta method. (3) *** 、** and * denote $1 \%$ 、5\% and $10 \%$ significance level, respectively.

From January 1999 to June 2005, except that Philippines has significant "fear of depreciation" inclination against both nominal exchange rate and nominal effective exchange rate, all the other six countries have significant "fear of appreciation" preference. This is because these countries draw lessons from the Asian financial crisis and they accumulate huge foreign exchange reserves through encouraging capital inflows, limiting capital outflows and conducting export-oriented international trade policy. But maintaining export competitiveness and huge foreign exchange reserves make these countries fear of domestic currencies appreciation, since appreciation would reduce export competitiveness by increasing export price and reduce capital value of foreign exchange reserves by revaluation effects. The reason of opposite results of the Philippines is that the nominal exchange rate of Philippine peso depreciates by $30.4 \%$ and the nominal effective exchange rate depreciates by $32.11 \%$ during this period. The Philippine government actively intervenes in foreign exchange market to curb rapid depreciation trend of Philippine peso. In addition, the degree of asymmetric foreign exchange market intervention against nominal exchange rate appreciation is greater than against nominal effective exchange rate in China and Korea, while India, Indonesia, Singapore and Thailand are just the opposite.

As can be seen from the contrast of estimation results of above two subsample periods, when the Asian financial crisis breaks out, all sample countries conduct active asymmetric intervention in foreign exchange market to defense depreciation. But after the Asian financial crisis, since most emerging Asian economies implement export-oriented international trade policy and begin to hoard foreign exchange reserves, these countries gradually transit from "fear of depreciation" to "fear of appreciation" asymmetric foreign exchange market intervention preference. In addition, during the Asian financial crisis, most countries conduct stronger foreign exchange market intervention against nominal exchange rate compared to nominal effective exchange rate. However, estimation results reverse after the Asian financial crisis. This is probably because a large part of economic growth in Asian countries derives from international trade. Therefore, during non-financial crisis, these countries pay more attention to enhance their competitiveness in international trade.

From July 2005 to August 2008, central Banks in all countries have "fear of appreciation" asymmetric foreign exchange market intervention preference. In July 2005, several emerging Asian economies conduct reform of exchange rate regime and implement more flexible exchange rate regime, therefore, except Indonesia and the Philippines, the five other emerging Asian economies conduct smaller asymmetric foreign exchange market intervention. 
The estimation results of the time period from September 2008 to December 2015 are similar to those in last subsample period. The difference is that the degree of asymmetric intervention against nominal exchange rate appreciation rises in Indonesia, Korea, the Philippines, Singapore and Thailand, while the degree of asymmetric intervention against nominal effective exchange rate appreciation rises in Indonesia, Korea and the Philippines. This is mainly because the global financial crisis triggered by the US subprime mortgage crisis break out in 2008 and the US economy is seriously impacted. Hence, the Federal Reserve begins to implement quantitative easing policy since November 2008 and the dollar continues to depreciate while many emerging Asian economies are forced to appreciate, which seriously affects export in these countries. Thus, after the global financial crisis, these emerging Asian economies have a "fear of appreciation" intervention preference, especially fear of domestic currencies appreciation relative to the dollar.

As can be seen from the contrast of estimation results of above two subsamples, before the global financial crisis, the degree of asymmetric intervention against domestic currencies appreciation in most countries have declined owing to the reform of exchange rate regime. However, after the global financial crisis breaking out, these countries enhance the degree of asymmetric foreign exchange rate market intervention against domestic currencies appreciation, especially domestic currencies nominal exchange rate relative to the US dollar.

\section{Conclusion}

Following the model and method of Srinivasan et al. (2009), this paper estimates asymmetric preference of central bank foreign exchange market intervention in seven emerging Asian economies in four subsample periods to reveal the impact of financial crisis on exchange rate management preference in emerging Asian economies.

During the Asian financial crisis, all sample countries conduct significant "fear of depreciation" asymmetric foreign exchange market intervention and begin to accumulate foreign exchange reserves. The international trade policies and huge foreign exchange reserves make all sample countries except the Philippines transit from "fear of depreciation" to "fear of appreciation" asymmetric foreign exchange market intervention after Asian financial crisis.

Despite most emerging Asian economies reduce the degree of asymmetric intervention after the reform of exchange rate regime in July 2005. However, since the Fed conducts quantitative easing policies to deal with the global financial crisis, these countries raise the degree of "fear of appreciation" asymmetric intervention to maintain export competitiveness and minimize the impact of world economic recession on domestic economic development.

In addition, this paper finds that more emerging Asian economies tend to conduct stronger asymmetric intervention against domestic currency nominal exchange rate in the period of financial crisis, while conduct stronger asymmetric intervention against domestic currency nominal effective exchange rate in the period of non-financial crisis. The results imply that these emerging Asian economies pay more attention to maintain their export competitiveness in stable stage of economic development. However, facing serious economic fluctuations, such as the financial crisis, they pay close attention to their nominal exchange rate against the US dollar.

\section{Acknowledgements}

This work was financially supported by China Scholarship Council and the Fundamental Research Funds for the Central Universities (14ZZ2109).

\section{References}

[1] Levy-Yeyati E, Sturzenegger F. Fear of Floating in Reverse: Exchange Rate Policy in the 2000s[J].2007.

[2] Ramachandran M, Srinivasan N. Asymmetric Exchange Rate Intervention and International 
Reserve Accumulation in India[J]. Economics Letters, 2007, 94(2): 259-265.

[3] Srinivasan N, Mahambare V, and Ramachandran M.. Preference Asymmetry and International Reserve Accretion in India[J]. Applied economics letters, 2009, 16(15): 1543-1546.

[4] Cavoli T, Pontines V, Rajan R S. Managed Floating by Stealth: the Case of Taiwan[J]. Journal of the Asia Pacific Economy, 2012, 17(3): 514-526.

[5] Pontines V, Rajan R S. Foreign Exchange Market Intervention and Reserve Accumulation in Emerging Asia: Is There Evidence of Fear of Appreciation?[J]. Economics Letters, 2011, 111(3): 252-255.

[6] Rajan R S. Management of Exchange Rate Regimes in Emerging Asia[R]. Asian Development Bank Institute, 2011.

[7] Stigler M, Patnaik I, Shah A. Asymmetries in Central Bank Intervention[J]. 2009,12.

[8] Pontines V, Siregar R Y. Fear of Appreciation in East and Southeast Asia: The Role of the Chinese Renminbi[J]. Journal of Asian Economics, 2012, 23(4): 324-334.

[9] Pontines V, Siregar R Y. Exchange rate asymmetry and flexible exchange rates under inflation targeting regimes: evidence from four East and Southeast Asian countries[J]. Review of International Economics, 2012, 20(5): 893-908.

[10] Du X R, Huang Z Q, Wang Yanna. China's Foreign Exchange Reserves Accumulation and the Central Bank’S Asymmetric Intervention in the Foreign Exchange Market[J]. International Economic Cooperation, 2010 (11): 90-94.

[11] Wang Jinbin, Li Nan. A Note on the Defensive Orientation of the Renminbi Exchange Rate Policy[J]. Chinese Studies, 2014(3):56-66. 